\title{
A Case of Acute Myeloid Leukemia With inv(16) (p13.1q22);CBFB-MYH11 Presenting With Faggot Cells
}

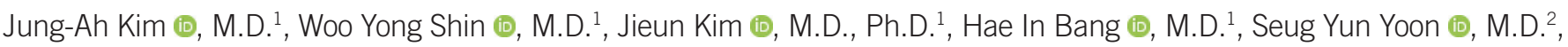
Jong-Ho Won (i), M.D., Ph.D. ${ }^{2}$, and Rojin Park (i), M.D., Ph.D. ${ }^{1}$

Departments of ${ }^{1}$ Laboratory Medicine and ${ }^{2}$ Internal Medicine, Soonchunhyang University Seoul Hospital, Seoul, Korea

\section{Dear Editor,}

Unlike in other acute myeloid leukemias (AMLs), in acute promyelocytic leukemia (APL), bleeding is the most common cause of early death. Thus, prompt treatment of patients with APL is necessary, and a presumptive APL diagnosis should be made, with immediate administration of all-trans retinoic acid (ATRA), which induces promyelocyte differentiation and can thus prevent coagulopathy, lowering mortality rate [1]. Faggot cells are immature cells with Auer rod bundles in the cytoplasm, characteristic of APL but have rarely been found in other AML types, including myelodysplastic syndrome [2-6]. We report an AML case presenting with several faggot cells in the bone marrow, which had caused a prompt ATRA treatment but was later diagnosed as concurrent AML with inv(16)(p13.1q22). The Institutional Review Board of Soonchunhyang University Hospital, Seoul, Korea, approved this study (IRB File No. 2020-05-020).

In January 2020, a 65-year-old woman complaining of sudden abdominal pain and diarrhea, was admitted to Soonchunhyang University Hospital. Initial complete blood counts were: $\mathrm{Hb}$, $64 \mathrm{~g} / \mathrm{L}(120-160 \mathrm{~g} / \mathrm{L}) ;$ platelet count, $43 \times 10^{9} / \mathrm{L}\left(130-450 \times 10^{9} / \mathrm{L}\right)$; and white blood cell count (WBC), $7.4 \times 10^{9} / \mathrm{L}\left(4.0-10.0 \times 10^{9} / \mathrm{L}\right)$. Coagulation test results were within normal range, except for the slightly prolonged prothrombin time at $12.4 \mathrm{sec}(9.3-11.6 \mathrm{sec}-$ onds). The peripheral blood smear showed $9 \%$ blasts based on all WBCs and bone marrow aspirate smear revealed $45.9 \%$ blasts, including $20.6 \%$ promonocytes, which have a morphologic picture resembling promyelocytes, based on ANCs. A variety of faggot cells (Fig. 1A, 1B, and 1C) were observed, with occasional observation of abnormal eosinophils. Most blasts were found to be positive for both myeloperoxidase and alpha-naphthyl acetate esterase on cytochemical staining.

Flow cytometric analysis (Navios EX Flow Cytometer and Kaluza Analysis Software, Beckman Coulter, Inc., Miami, FL, USA) demonstrated the presence of blasts expressing CD34, CD13, CD38, CD117, and HLA-DR and CD56 as an aberrant marker, consistent with $A M L$, and being negative for CD11c, CD14, and CD64. Given the possibility of APL based on morphological diagnosis, ATRA was administered to the patient. The next day, however, sequential FISH (CBFB/MYH11- Translocation, dual fusion probe, designed by Cytocell, Cambridge, UK and Metafer/Zeiss system, Metasystems, Altlussheim, Germany) and reverse-transcription PCR (GeneAmp PCR System 9700, Applied Biosystems, Foster City, CA, USA) revealed CBFB-MYH11 rearrangement (Fig. 1D) in the absence of $P M L-R A R A$ rearrangement. Hence, ATRA was discontinued.

Cytogenetic analysis revealed 47,XX,inv(16)(p13.1q22),+22 [17]/46,XX[3] (Fig. 1E). The p.Asp816His variant in KIT represented $32.0 \%$ of the total depth in targeted next-generation sequencing (Customized panel, designed by Celemics, Inc., Seoul,
Received: May 28, 2020

Revision received: July 2, 2020

Accepted: November 17, 2020

Corresponding author: Rojin Park, M.D., Ph.D. Department of Laboratory Medicine, Soonchunhyang University Seoul Hospital, 59 Daesagwan-ro, Yongsan-gu, Seoul 04401, Korea Tel: +82-2-709-9427, Fax: +82-2-710-3184

E-mail: rpark@schmc.ac.kr

\section{(c) (i) (5)}

(C) Korean Society for Laboratory Medicine

This is an Open Access article distributed under the terms of the Creative Commons Attribution Non-Commercial License (https://creativecommons.org/licenses/by-nc/4.0) which permits unrestricted non-commercial use, distribution, and reproduction in any medium, provided the original work is properly cited. 

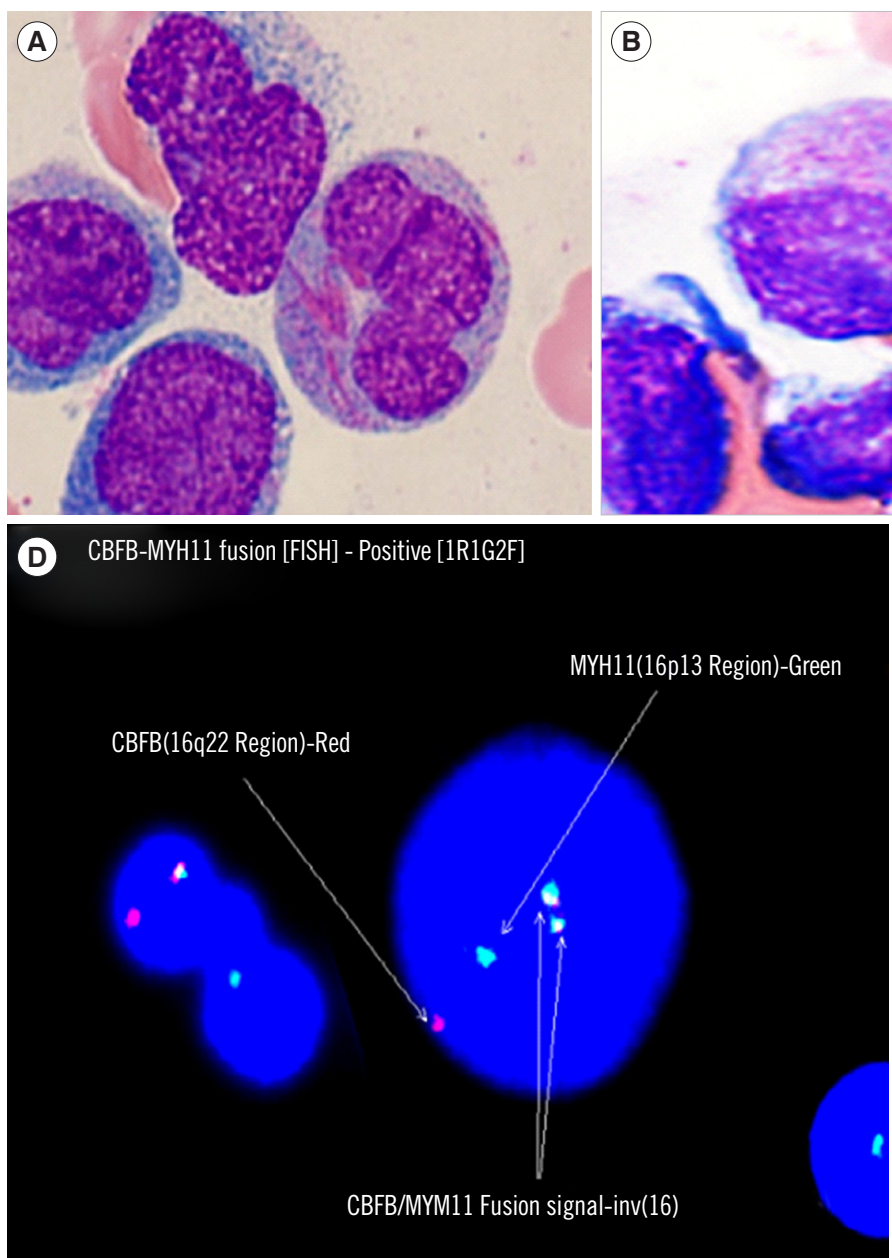

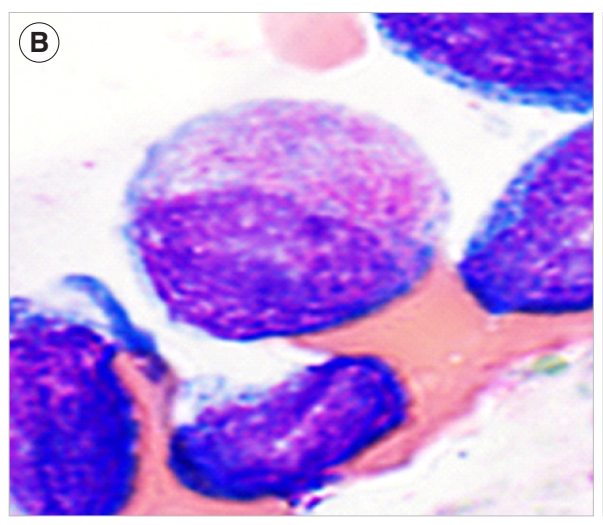

(C)

(E)
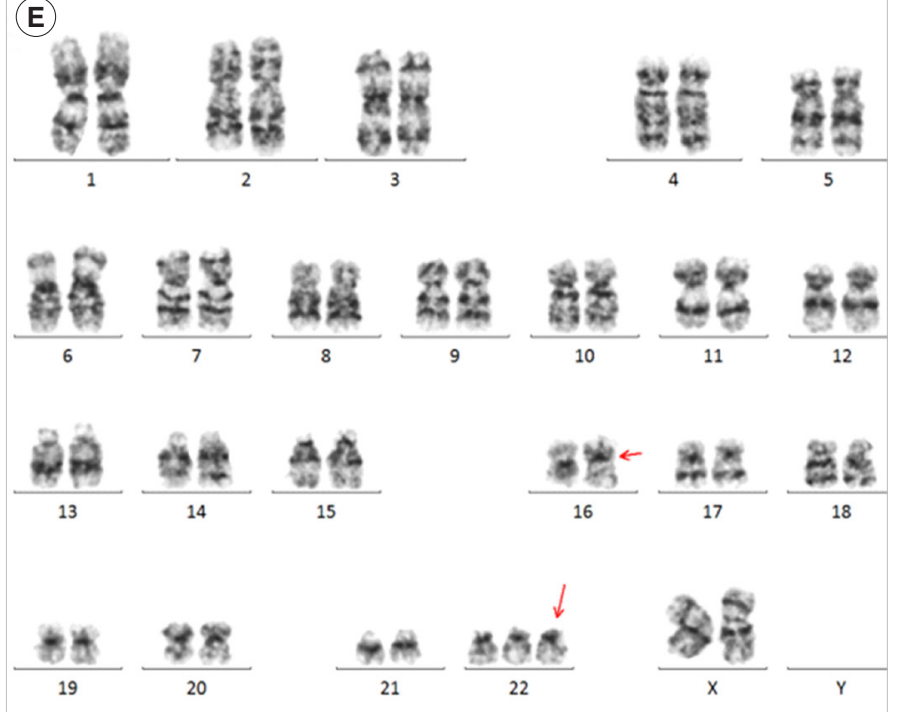

Fig. 1. Morphology, FISH, and cytogenetics of bone marrow. (A-C) Aspirate smears (Wright-Giemsa stain; magnification, 1,000 $x$ ) showing a variety of faggot cells. (D) FISH analysis showing CBFB-MYH11 gene rearrangement by inv(16) (white arrow). (E) Conventional cytogenetics showing 47,XX,inv(16)(p13.1q22),+22.

Abbreviation: CBFB, core-binding factor subunit beta.

Korea; NGS platform, Illumina MiSeq DX, San Diego, CA, USA). Based on these findings, the patient was diagnosed as having AML with inv(16)(p13.1q22);CBFB-MYH11, and a standard AML induction chemotherapeutic regimen, including idarubicin and cytarabine, was started. After a month of induction chemotherapy, bone marrow examination showed that the patient achieved complete hematologic and cytogenetic responses, without faggot cells. The patient is currently well and undergoing consolidation therapy.

Faggot cells presence in AML with recurrent genetic abnormalities (by 2017 WHO classification) other than APL has been mainly reported to accompany core binding factor (CBF) variants, especially, t(8;21) and inv(16) [4-7]. CBF variants cause CBF complex decomposition to block cell differentiation. In addition to ours, three AML cases with faggot cells accompanied by inv(16) have been reported [4-6]. Two cases were de novo
AML with inv(16) harboring a KIT variant, as in our case [4, 5], and the other case was therapy-related AML with inv(16)(p13. 1q22) in a patient treated for HIV infection and Hodgkin lymphoma [6]. Clinical features and hematologic findings of these cases and ours are summarized in Table 1.

Faggot cells presence is not sufficient for APL diagnosis, but there is diagnostic value of faggot cell detection in APL for ATRA treatment in the early disease stage to prevent coagulopathy, since APL has a high mortality rate due to disseminated intravascular coagulation [8]. In line with our case, trisomy 22 in AML with inv(16) was reported to have favorable prognosis; however, presence of a KIT (p.Asp816His) variant in AML may have adverse prognostic significance [9]. To investigate the prognosis of non-APL AML with faggot cells, further studies may be needed.

In summary, we report a rare AML case with inv(16)(p13.1q22); 
Table 1. Characteristics of four AML cases with inv(16)(p13.1q22) with faggot cells

\begin{tabular}{|c|c|c|c|c|}
\hline & *Present case & *Jerez et al. [4] & *Garrastazul-Sánchez et al. [5] & *Kim et al. [6] \\
\hline Sex/age (yr) & $\mathrm{F} / 65$ & $M / 32$ & $M / 36$ & $\mathrm{M} / 12$ \\
\hline Underlying disease & DM, colon adenoma & HIV infection, Hodgkin lymphoma & None & None \\
\hline Initial CBC & $\begin{array}{l}\text { WBC count } 9.4 \times 10^{9} / \mathrm{L} \\
\text { Hb } 95 \mathrm{~g} / \mathrm{L} \\
\text { Platelet count } 37 \times 10^{9} / \mathrm{L}\end{array}$ & $\begin{array}{l}\text { WBC count } 67.4 \times 10^{9} / \mathrm{L} \\
\mathrm{Hb} 85 \mathrm{~g} / \mathrm{L} \\
\text { Platelet count } 10 \times 10^{9} / \mathrm{L}\end{array}$ & $\begin{array}{l}\text { WBC count } 22.0 \times 10^{9} / \mathrm{L} \\
\text { Hb } 98 \mathrm{~g} / \mathrm{L} \\
\text { Platelet count } 42 \times 10^{9} / \mathrm{L}\end{array}$ & $\begin{array}{l}\text { WBC count } 20.85 \times 10^{9} / \mathrm{L} \\
\text { Hb } 106 \mathrm{~g} / \mathrm{L} \\
\text { Platelet count } 55 \times 10^{9} / \mathrm{L}\end{array}$ \\
\hline Cytogenetic study & $\begin{array}{l}\text { 47,XX,inv(16)(p13.1q22), } \\
\quad+22[17] / 46, X X[3]\end{array}$ & $47, X Y,+8, \operatorname{inv}(16)(p 13 q 22)[20]$ & $\begin{array}{l}\text { inv(16) and hyperdiploidy of } 52 \\
\text { chromosomes }\end{array}$ & $\begin{array}{l}\text { 47,XY,inv(16) } \\
\quad(p 13.1 q 22),+22[20]\end{array}$ \\
\hline $\begin{array}{l}\text { Molecular study (rearrangement } \\
\text { /variant) }\end{array}$ & $\begin{array}{l}\text { CBFB-MYH11 } \\
\text { KIT (p.Asp816Val) }\end{array}$ & CBFB-MYH11 & $\begin{array}{l}\text { CBFB-MYH11 } \\
\text { KIT (p.Asp816Val) }\end{array}$ & KIT (p.Asp816Tyr) \\
\hline Disease course & CR after induction CTx & CR after induction CTx & CR after induction CTx & Died two days after remission \\
\hline
\end{tabular}

${ }^{*}$ All cases did not present with DIC.

Abbreviations: DM, diabetes mellitus; CBC, complete blood count; CR, complete remission; CTx, chemotherapy; DIC, disseminated intravascular coagulation; F, female; M, male; WBC, white blood cell count; CBFB, core-binding factor subunit beta.

CBFB-MYH11, resembling APL due to faggot cell presence. While prompt treatment with ATRA is crucial for APL, final diagnosis should be made carefully. Accurate diagnosis based on a combination of additional laboratory findings is recommended, since AML subtypes differ in disease progress, treatment choice, treatment response, and prognosis.

\section{ACKNOWLEDGEMENTS}

None.

\section{AUTHOR CONTRIBUTIONS}

Park R conceived the study; Kim JA contributed to the interpretation of the results and initial drafting of the manuscript; and Shin WY, Kim J, and Bang HI contributed to the analysis and interpretation of the results. All authors contributed to writing the manuscript and approved the final version of the manuscript.

\section{CONFLICTS OF INTEREST}

None.

\section{RESEARCH FUNDING}

This work was supported by Soonchunhyang University research funding (SCH 2020-05-020).

\section{ORCID}

Jung-Ah Kim

https://orcid.org/0000-0003-1295-4728
Woo Yong Shin

Jieun Kim

Hae In Bang

Seug Yun Yoon

Jong-Ho Won

Rojin Park https://orcid.org/0000-0001-5588-6919 https://orcid.org/0000-0002-7794-3475 https://orcid.org/0000-0001-7854-3011 https://orcid.org/0000-0001-8228-0218 https://orcid.org/0000-0001-6176-1442 https://orcid.org/0000-0003-2866-037X

\section{REFERENCES}

1. Tallman MS and Altman JK. How I treat acute promyelocytic leukemia. Blood 2009;114:5126-35.

2. Ogura $H$, Inagaki A, Wakita A. A case of myelodysplastic syndrome presenting with faggot-like cells. Int J Hematol 2013;97:443-5.

3. Ohnishi $H$, Yoshino H, Yoneyama R, Ishii M, Watanabe T, Bessho F. Faggot formation in mature neutrophils and metamyelocytes in acute myeloid leukemia without maturation. Pediatr Hematol Oncol 2008;25:165-70.

4. Jerez A, del Mar Osma M, Amigo M, Ortuño FJ. Faggot cells in an HIVpositive patient with inv(16)/therapy-related acute myeloid leukaemia. Br J Haematol 2010;150:646.

5. Garrastazul-Sánchez MP, Vilches-Moreno M, Fernández-Valle MC, Marchante-Cepillo I, Prats-Martín C, Bernal R, et al. Neutrophil faggot cells and inv(16): not such a fortuitous association? Ann Hematol 2019;98: 1293-5.

6. Kim KJ and Kim IS. Bundles of Auer rods in mature neutrophils in a pediatric acute myeloid leukemia patient with inv(16)(p13.1q22). Int J Lab Hematol 2020;42:e164-6.

7. Gupta A, Reddy KG, Goyal M. "Faggot neutrophils!" in non-acute promyelocytic leukemia: a rare occurrence. Indian J Hematol Blood Transfus 2018;34:778-80.

8. Chang H, Kuo MC, Shih LY, Dunn P, Wang PN, Wu JH, et al. Clinical bleeding events and laboratory coagulation profiles in acute promyelocytic leukemia. Eur J Haematol 2012;88:321-8.

9. Paschka P, Du J, Schlenk RF, Gaidzik VI, Bullinger L, Corbacioglu A, et al. Secondary genetic lesions in acute myeloid leukemia with inv(16) or $\mathrm{t}(16 ; 16)$ : a study of the German-Austrian AML Study Group (AMLSG). Blood 2013;121:170-7. 